Bangl. J. Vet. Med. (2010). 8(1) : $17-21$

\title{
HOST DETERMINANTS BASED COMPARATIVE PREVALENCE OF SUBCLINICAL MASTITIS IN LACTATING HOLSTEIN-FRIESIAN CROSS COWS AND RED CHITTAGONG COWS IN BANGLADESH
}

\author{
A. F. M. G. Rabbani* and M. A. Samad \\ Department of Medicine, Faculty of Veterinary Science, Bangladesh Agricultural University, Mymensingh-2202, \\ Bangladesh. e-mail: masamad88bau@yahoo.com
}

\begin{abstract}
A comparative prevalence of sub-clinical mastitis (SCM) based on host risk factors was studied by using California Mastitis Test (CMT) in 96 Holstein-Friesian cross cows (HFCC) of Abu Baker Dairy Farm at Pansha Upazilla in Rajbari district and 20 Red Chittagong cows (RCC) of Bangladesh Agricultural University Dairy Farm (BAUDF), Mymensingh during the period from January to June 2008. Out of the 116 lactating cows examined, 51 (43.97\%) showed positive reactivity to CMT. Similar prevalence rate of SCM was recorded in both the HFCC (43.75\%) and RCC (45.0\%). The overall prevalence of SCM on the basis of lactation stages showed that all the three lactation stages had SCM but there was a tendency to increase its prevalence rates from early (30.43\%), mid (32.26\%) to late (69.23\%) stages. The highest prevalence of SCM was recorded at late lactation stage in both the HFCC (68.75\%) and RCC (71.43\%) in comparison to their respective mid and early lactation stages. The parity-wise prevalence of SCM was recorded as $18.42 \%, 55.0 \%, 66.67 \%, 75.0 \%$ and $75.0 \%$ in HFCC whereas, it was $20.0 \%, 20.0 \%, 66.67 \%, 75.0 \%$ and $66.67 \%$ in RCC at their $1^{\text {st }}, 2^{\text {nd }}, 3^{\text {rd }}, 4^{\text {th }}$ and $5^{\text {th }}$ parity, respectively. This study recorded a relationship between the increased prevalence of SCM with decreased of milk production in both the groups of lactating cows. The respective prevalence of SCM at high, medium and low level of milk production in HFC (14.29\%, 33.33\% and $70.59 \%)$ and RCC (14.29\%, 50.00\% and 71.42\%) were found significantly ( $<$ < 0.01) correlated with milk production. An overall $19.18 \%$ quarters was affected with SCM, of which $4.31 \%, 7.33 \%$ and $7.38 \%$ showed mild, moderate and severe reaction to CMT. However, comparatively, higher percentage of quarter infection was recorded in HFCC (20.31\%) than RCC (13.75\%). It may be concluded from these observations that both the HFCC and RCC should be monitored by using CMT for the detection of SCM in order to provide rational treatment and control it to make the dairy farming profitable.
\end{abstract}

Key words: Holstein-Friesian cross-bred cows, Red Chittagong cows, Host risk factors, Sub-clinical mastitis, California Mastitis Test.

\section{INTRODUCTION}

Bovine mastitis is the costly disease to the dairy industry worldwide and it is mainly categorized into clinical mastitis (CM) and sub-clinical mastitis (SCM). The CM is characterized by signs of inflammation of the udder and changes in the milk whereas in SCM, the milk appears grossly normal, no visible signs of inflammation of the udder but the inflammatory reaction is detectable only by indirect tests like CMT and culturing milk of all quarters. It is now a well known fact that the sub-clinical mastitis (SCM) is more serious and is responsible for much greater loss to the dairy industry in Bangladesh (Kader et al., 2003). Singh and Singh (1994) reported more than three times losses due to SCM as compared to clinical mastitis (CM). The annual economic losses occur due to reduced milk production alone caused by SCM in Bangladesh have been estimated to be Taka 122.6 (US \$ 2.11) million (Kader et al., 2003). Besides causing huge economic losses to milk production, the SCM remain a continuous source of infection to other herd mates. If the infection persists for longer periods, then it may form a fibrous tissue barrier between the organisms and the antibiotic preparations, thus, limiting their efficacy. It is, therefore, important to know the prevalence of SCM in dairy herds and delineate the important factors responsible for it. The SCM can be known only after laboratory examination, as there are no gross inflammatory changes in the udder tissue. California Mastitis Test (CMT) has been recognized as a highly sensitive to test to detect bovine SCM (Dangore et al., 2000; Sachin and Suresh 2006; Madut et al., 2009). The Red Chittagong cows (RCC) is the only recognized cattle variety available in Bangladesh and recently an attention has been given on this cattle at national levels for its development and proper utilization in the livestock industry in Bangladesh. Although inland research reports on mastitis have been made on the zebu and cross-bred cattle of Bangladesh have been reviewed (Samad, 2000) but there seems to be no such report on RCC. This paper describes the comparative prevalence of SCM associated with host risk factors in HFCC and RCC.

*Part of MS research 


\section{A. F. M. G Rabbani and M. A. Samad}

\section{MATERIALS AND METHODS}

This study on the prevalence of SCM was carried on randomly selected 20 RCC maintained at the BAUDF, Mymensingh and 96 HFCC of a private dairy farm (Abu Baker Dairy Farm, Upazila- Pansha, District- Rajbari ) during the period from January to June 2008. These randomly selected lactating cows were aged between 2 to 8 years, at different lactation stages, parity and level of milk production (Table 2).

Milk samples ( $2 \mathrm{ml}$ / quarter) from each quarter of the randomly selected apparently healthy 116 lactating cows (96 HFCC and 20 RCC) were collected in sterilized epen-drop tubes. These collected milk samples were tested immediately after collection of the milk samples by using California Mastitis Test (CMT) kit (Leucocytest ${ }^{\circledR}$, Synbiotics Corporation, France). Each set of Leucocyst test kit contains Leucocystest Reactionlif: 1 vial of 1 liter and Leucocyst plate: 1 plate of 4 wells. The test was conducted as per the manufacturer instruction. Briefly, equal volumes $(2.0 \mathrm{ml})$ commercial CMT reagent and quarter milk were mixed and the changes in milk fluidity and viscosity were observed. The interpretation of the result was done according to the instruction. Negative $(0)$ and Trace $( \pm$ ) were considered as negative and different intensities of positive (1,2 and 3 ) were considered as positive (Table 1).

Table 1. Interpretation of the CMT results

\begin{tabular}{|c|c|c|c|c|}
\hline \multicolumn{2}{|c|}{ Score } & \multirow[t]{2}{*}{ Visible reaction } & \multirow[t]{2}{*}{ Infection } & \multirow{2}{*}{$\begin{array}{l}\text { Related with the average } \\
\text { cellular numeration } \\
\left(\times 10^{3} / \mathrm{ml}\right)\end{array}$} \\
\hline Value & e Cross & & & \\
\hline 0 & Negative (0) & $\begin{array}{l}\text { Consistency normal } \\
\text { or gray color. }\end{array}$ & Absent & 100 \\
\hline-7 & Trace $( \pm)$ & $\begin{array}{l}\text { Slight precipitation } \\
\text { disappearing after } \\
\text { stirring or purplish } \\
\text { gray color. }\end{array}$ & $\begin{array}{l}\text { Infection risk by } \\
\text { minor pathogens. }\end{array}$ & 300 \\
\hline 1 & Weak positive $(1+)$ & $\begin{array}{l}\text { Distinct precipitation } \\
\text { but no gel formation } \\
\text { or purple gray. }\end{array}$ & Sub-clinical mastitis & 900 \\
\hline 2 & Distinct positive $(2+)$ & $\begin{array}{l}\text { Mixture thickness with } \\
\text { a gel formation. }\end{array}$ & Sub-clinical mastitis & 2700 \\
\hline 3 & Strong positive $(3+)$ & $\begin{array}{l}\text { Thick gel. Consistency } \\
\text { of egg white color dark } \\
\text { purple. }\end{array}$ & $\begin{array}{l}\text { Sub-clinical mastitis } \\
\text { near the clinical } \\
\text { expression. }\end{array}$ & 8100 \\
\hline
\end{tabular}

\section{Statistical analysis}

Microsoft excels 2000 and stata 6.0 for Windows 98/95/NT were used for data analysis. Descriptive statistics were used for all the variables. Chi-square $\left(\mathrm{X}^{2}\right)$ was used for assessing the statistical associations of various factors with mastitis (Steel and Torrie, 1980).

\section{RESULTS AND DISCUSSION}

Bovine mastitis is a single most common disease syndrome in adult dairy cows, recognized manly as clinical and sub-clinical types worldwide. It is estimated that one third of all dairy cows are infected with some form of mastitis in one or more quarters. Mastitis is also associated with number of zoonotic diseases in which milk acts as a vehicle of infection (Samad, 2008). The sub-clinical mastitis (SCM) has been recognized to be more economically important than clinical mastitis (CM) worldwide including Bangladesh (Singh and Singh, 1994; 
Kader et al.,2003 ; Sachin and Suresh 2006). Although some research works on mastitis in HFCC have been made but reports on mastitis in RCC are limited (Samad, 2000). Therefore, an attempt was made to study the comparative prevalence of SCM with host determinants between HFCF and RCC.

\section{Overall prevalence of SCM}

The milk samples of 96 lactating HFCC and 20 RCC were screened for infection using CMT, of which $43.75 \%$ and $45.0 \%$ cows were affected with SCM (Table 2). These prevalence rates support the earlier reports of Singh and Baxi (1988) who reported 54.0\% prevalence of SCM in India and Kader et al. (2002) who reported 46.6\% SCM in cross-bred lactating cows on bacteriological examination of milk samples in Bangladesh. However, both lower (Sen et al., 1996; Nooruddin et al., 1997; Rahman et al., 1997) and higher (Motice et al., 1985; Ramachandraiah et al., 1990) prevalence rates of SCM have been reported in the literature. These differences of prevalence rates of SCM might be due to difference of breeds of animals, management practices and the tests used for screening of the milk samples.

\section{Prevalence of SCM at different stages of lactation}

The prevalence of SCM was analyzed on the basis of three stages (early, mid and late) of lactation in both the HFCC and RCC and the results are presented in Table 2. It appears from the Table 2 that all the three stages of lactation in both the HFCC and RCC affected with SCM. The prevalence of SCM was recorded in 31.58\%, $30.77 \%$ and $68.75 \%$ in HFCC, and $25.0 \%, 40.0 \%$ and $71.43 \%$ in RCC during the early, mid and late stages of lactation, respectively (Table 2). The highest prevalence of SCM was recorded during the last lactation stage in both the HFCC (68.75\%) and RCC (71.43\%) in comparison to there respective mid and early stages of lactation (Table 2). These results are in conformity with the earlier finding of Rahman et al. (1997) who reported higher prevalence of SCM during the $3^{\text {rd }}$ months (34\%) of lactation. However, these results contradict with Pal and Verma (1988) who reported lower prevalence of SCM in stages of lactation above five months. Review of literature revealed that the higher incidence of CM usually occurred during early stage of lactation due to high yielding enlarged status of udder which is particularly prone to infection and inflammatory process due to physiological stress strain of heavy milk production, but the prevalence of SCM could be high at late stage of lactation due long exposure time.

\section{Prevalence of SCM on the basis of parity}

The prevalence of SCM was analyzed on the basis of parity in both the HFCC and RCC (Table 2). The prevalence of SCM in HFCC was recorded as $18.42 \%, 55.0 \%, 66.67 \%, 75.0 \%$ and $75.0 \%$, whereas it was $20.0 \%$, $20.0 \%, 66.67 \%, 75.0 \%$ and $66.67 \%$ in RCC at the $1^{\text {st }}, 2^{\text {nd }}, 3^{\text {rd }}, 4^{\text {th }}$ and $5^{\text {th }}$ parity, respectively (Table 2). It indicates that the prevalence of SCM was found highest at $4^{\text {th }}(75.0 \%)$ and $5^{\text {th }}(75.0 \%)$ parity in HFCC and at $4^{\text {th }}$ (75.0\%) parity in RCC in comparison to $1^{\text {st }}$ and $2^{\text {nd }}$ parity but an increasing tendency was recorded with increased of parity. This observation supports the reports of Rasool et al. (1985), Devi et al. (1997) and Dego and Tareke (2003).

\section{Prevalence of SCM on the basis of milk production}

The prevalence of SCM on the basis of milk production in both the HFCC and RCC is presented Table 2. The selected lactating cows were grouped into three on the basis of milk production (high, medium and low) and the highest prevalence of SCM was recorded in cows with low milk production in both the HFCC and RCC (Table 2). These results indicate that there is a relationship between the prevalence of SCM and decrease of milk production. These findings supports the reports of Verma (1978), Singh and Singh (1994) and Kader et al. (2003) who reported economic losses caused by reduction of milk production in SCM affected lactating cows.

\section{Quarter-wise prevalence of SCM}

The milk samples of 96 HFCC which consisted of 384 quarters and 20 RCC which consisted of 80 quarters samples were screened by using CMT, of which 78 (20.31\%) HFCC and 11 (13.75\%) RCC samples were found positive for SCM (Table 2). The quarter-wise overall prevalence of SCM was found comparatively higher at both the right front $(20.69 \%)$ and right hind $(24.14 \%)$ quarters in comparison to left front $(15.52 \%)$ and left hind (15.52\%) quarters (Table 2). However, Lalrintluangu et al. (2003) reported the incidence of clinical mastitis more frequently in left hind quarters (30.25\%) in cows. 


\section{A. F. M. G. Rabbani and M. A. Samad}

Table 2. Host determinants associated prevalence of sub-clinical mastitis (SCM) in lactating cows detected by California Mastitis Test (CMT)

\begin{tabular}{|c|c|c|c|c|c|c|c|c|}
\hline \multirow[t]{4}{*}{$\mathrm{S} / \mathrm{N}$} & \multirow[t]{4}{*}{ Risk factors } & \multirow[t]{4}{*}{ Types } & \multirow{2}{*}{\multicolumn{2}{|c|}{$\begin{array}{l}\text { Holstein-Friesian } \\
\text { cross-bred cows }\end{array}$}} & \multirow{2}{*}{\multicolumn{2}{|c|}{$\begin{array}{l}\text { Red Chittagong } \\
\text { cows }\end{array}$}} & \multicolumn{2}{|l|}{ Overall } \\
\hline & & & & & & & \multirow{3}{*}{$\begin{array}{l}\text { No. of } \\
\text { cows } \\
\text { tested }\end{array}$} & \\
\hline & & & \multirow{2}{*}{$\begin{array}{l}\text { No. of } \\
\text { cows } \\
\text { tested }\end{array}$} & $\overline{\text { Positive }}$ & \multirow{2}{*}{$\begin{array}{l}\text { No. of } \\
\text { cows } \\
\text { tested }\end{array}$} & \multirow{2}{*}{$\begin{array}{l}\text { Positive } \\
\text { No. (\%) }\end{array}$} & & \multirow{2}{*}{$\begin{array}{l}\text { Positive } \\
\text { No. (\%) }\end{array}$} \\
\hline & & & & No. (\%) & & & & \\
\hline \multirow[t]{4}{*}{ (1) } & \multirow{4}{*}{$\begin{array}{l}\text { Stage of } \\
\text { lactation }\end{array}$} & Early (6-90d) & 38 & 12 (31.58) & 8 & $2(25.00)$ & 46 & $14(30.43)$ \\
\hline & & Mid (91-180d) & 26 & 08 (30.77) & 5 & $2(40.00)$ & 31 & $10(32.26)$ \\
\hline & & Late $(>180 \mathrm{~d})$ & 32 & $22(68.75)^{*}$ & 7 & 5 (71.43)* & 39 & $27(69.23) *$ \\
\hline & & Sub-total: & 96 & 42 (43.75) & 20 & $9(45.00)$ & 116 & 51 (43.97) \\
\hline \multirow[t]{6}{*}{ (2) } & \multirow[t]{6}{*}{ Parity } & 1 & 38 & 07 (18.42) & 5 & $1(20.00)$ & 43 & $08(18.60)$ \\
\hline & & 2 & 40 & $22(55.00)$ & 5 & $1(20.00)$ & 45 & $23(51.11)$ \\
\hline & & 3 & 06 & 04 (66.67) & 3 & 2 (66.67) & 09 & 06 (66.67) \\
\hline & & 4 & 04 & $03(75.00)^{*}$ & 4 & $3(75.00)^{*}$ & 08 & $06(75.00)^{*}$ \\
\hline & & 5 & 08 & $06(75.00)^{*}$ & 3 & $2(66.67)$ & 11 & 08 (72.73) \\
\hline & & Sub-total: & 96 & $42(43.75)$ & 20 & $9(45.00)$ & 116 & 51 (43.97) \\
\hline \multirow[t]{4}{*}{ (3) } & \multirow{4}{*}{$\begin{array}{l}\text { Milk yield+ } \\
\text { (liter/day) }\end{array}$} & High & 14 & 02 (14.29) & 7 & 1 (14.29) & 21 & 03 (14.29) \\
\hline & & Medium & 48 & 16 (33.33) & 6 & $3(50.00)$ & 54 & 19 (35.29) \\
\hline & & Low & 34 & 24 (70.59)* & 7 & 5 (71.42)* & 41 & $29(70.73) *$ \\
\hline & & Sub-total: & 96 & 42 (43.75) & 20 & $9(45.00)$ & 116 & 51 (43.97) \\
\hline \multirow[t]{5}{*}{ (4) } & \multirow[t]{5}{*}{ Quarter } & LF & 96 & $16(16.67)$ & 20 & 02 (11.76) & 116 & $18(15.52)$ \\
\hline & & $\mathrm{LH}$ & 96 & 16 (16.67) & 20 & $02(11.76)$ & 116 & $18(15.52)$ \\
\hline & & $\mathrm{RF}$ & 96 & 23 (23.96) & 20 & $01(05.88)$ & 116 & 24 (20.69) \\
\hline & & $\mathrm{RH}$ & 96 & 23 (23.96) & 20 & 05 (23.50) & 116 & $28(24.14)$ \\
\hline & & Sub-total: & 384 & 78 (20.31) & 80 & $11(13.75)$ & 464 & 89 (19.18) \\
\hline
\end{tabular}

+HF cross cows: Low 1-5 liter, Medium 6-9 liter and High $\geq 10$ liter; RCC: Low 0.5-1 liter, Medium >1-2 liter and High $>2$ liter *Significantly $(\mathrm{p}<0.01)$ increased.

These results showed that stages of lactation, parity, level of milk yield and quarter location are the important host factors associated with the prevalence of SCM in cows. Therefore, this study suggests further studies to identify the environmental, pathogens and management risk factors and antibiotic sensitivity tests for the isolates as this would help to device treatment and control of SCM in dairy cows.

\section{REFERENCES}

1. Dangore AD, Bhalerao DP, Jagadish S, Keskar DV and Sharma LK (2000). Evaluation of some byre-side tests in bovine sub-clinical mastitis. Indian Veterinary Journal 77 : 380-381.

2. Dego OK and Tareke F (2003). Bovine mastitis in selected areas of Southern Ethiopia. Tropical Animal Health and Production 35 : 197-205.

3. Devi BK, Shukla PC and Bagherwal RK (1997). Incidence of sub-clinical mastitis in cows. Indian Journal of Dairy Science 50 : 477-478.

4. Kader MA, Samad MA, Saha S and Taleb MA (2002). Prevalence and etiology of sub-clinical mastitis with antibiotic sensitivity to isolated organisms among milch cows in Bangladesh. Indian Journal of Dairy Science 55 : 218-223.

5. Kader MA, Samad MA and Saha S (2003). Influence of host level factors on prevalence and economics of sub-clinical mastitis in dairy cows in Bangladesh. Indian Journal of Dairy Science 56 : 235-240.

6. Lalrintluangu C, Ralte EL and Hmarkunga (2003). Incidence of mastitis, bacteriology and antibiogram in dairy cattle in Aizawl, Mizoram. Indian Veterinary Journal 80 : 931-932. 
7. Madut NA, Godir AEA and El Jalil IM (2009). Host determinants of bovine mastitis in semi-intensive production system of Kharfoum State, Sudan. Journal of Cell and Animal Biology 3: 71-77.

8. Motice A, Ramudit S and Mohabir R (1985). Sub-clinical mastitis in dairy cattle in Guyana. Tropical Animal Health Product 17 : 245-246.

9. Nooruddin M, Ali KM and Debnath NC (1997). Retrospective epidemiologic study of periparturient diseases in dairy cows. 1. Clinical mastitis. Bangladesh Veterinarian $14: 43-47$.

10. Pal P and Verma BB (1988). Some observation on efficacy of indirect test for detection of sub-clinical mastitis. Indian Journal of Veterinary Medicine $8: 40-41$.

11. Rahman MS, Nooruddin M and Rahman MM (1997). Prevalence and distribution of mastitis in cross-bred and exotic dairy cows. Bangladesh Veterinary Journal 14 : 1-4.

12. Ramachandraiah K, Kumar KS and Sreemannarayana O (1990). Survey of mastitis in a pure Jersey herd. Indian Veterinary Journal 67 : 105-106.

13. Rasool G, Jabbar MA, Kazmi SE and Ahmed A (1985). Incidence of sub-clinical mastitis in Nilli-Ravi buffaloes and Sahiwal cows. Pakistan Veterinary Journal 5 : 76-78.

14. Sachin J and Suresh G (2006). Status of mastitis as an emerging disease in improved and periurban dairy farms in India. Annals of the New York Academy of Sciences 1081: 74-83.

15. Samad MA (2000). An overview of livestock research reports published during the twentieth century in Bangladesh. Bangladesh Veterinary Journal 34 : 53-149.

16. Samad MA (2008). Animal Husbandry and Veterinary Science. Volume 2. LEP Publication No. 11, BAU Campus, Mymensingh.

17. Sen MM, Kabir MH and Rahman A (1996). Application of indirect tests to detect sub-clinical mastitis in milch cows. Bangladesh Veterinary Journal 30 : 137-139.

18. Singh KB and Baxi KK (1988). Studies on the incidence and diagnosis of sub-clinical mastitis in milch animals. Indian Veterinary Journal 47 : 723-729.

19. Singh PJ and Sing KR (1994). A study of economic losses due to mastitis in India. Indian Journal of Dairy Science 47: 265-272.

20. Verma ND (1978). Comparative incidence and economic loss due to sub-clinical mastitis in the herd of zebu, cross-bred and exotic breeds of milch animals. Indian Veterinary Journal 55 : 7-12.

21. Steel RGD and Torrie JH (1980). Principles and Procedures of Statistics. $2^{\text {nd }}$ edn., McGraw Hill Book Company, Inc., London. 